This item was submitted to Loughborough's Research Repository by the author.

Items in Figshare are protected by copyright, with all rights reserved, unless otherwise indicated.

\title{
Anarchism, individualism and communism: William Morris's critique of anarcho-communism
}

\section{PLEASE CITE THE PUBLISHED VERSION}

http://www.palgrave.com/

\section{PUBLISHER}

Palgrave MacMillan (@ Alex Prichard, Ruth Kinna, Saku Pinta and Dave Berry)

\section{VERSION}

AM (Accepted Manuscript)

\section{LICENCE}

CC BY-NC-ND 4.0

\section{REPOSITORY RECORD}

Kinna, Ruth. 2019. "Anarchism, Individualism and Communism: William Morris's Critique of Anarchocommunism”. figshare. https://hdl.handle.net/2134/12730. 
This item was submitted to Loughborough's Institutional Repository (https://dspace.lboro.ac.uk/) by the author and is made available under the following Creative Commons Licence conditions.

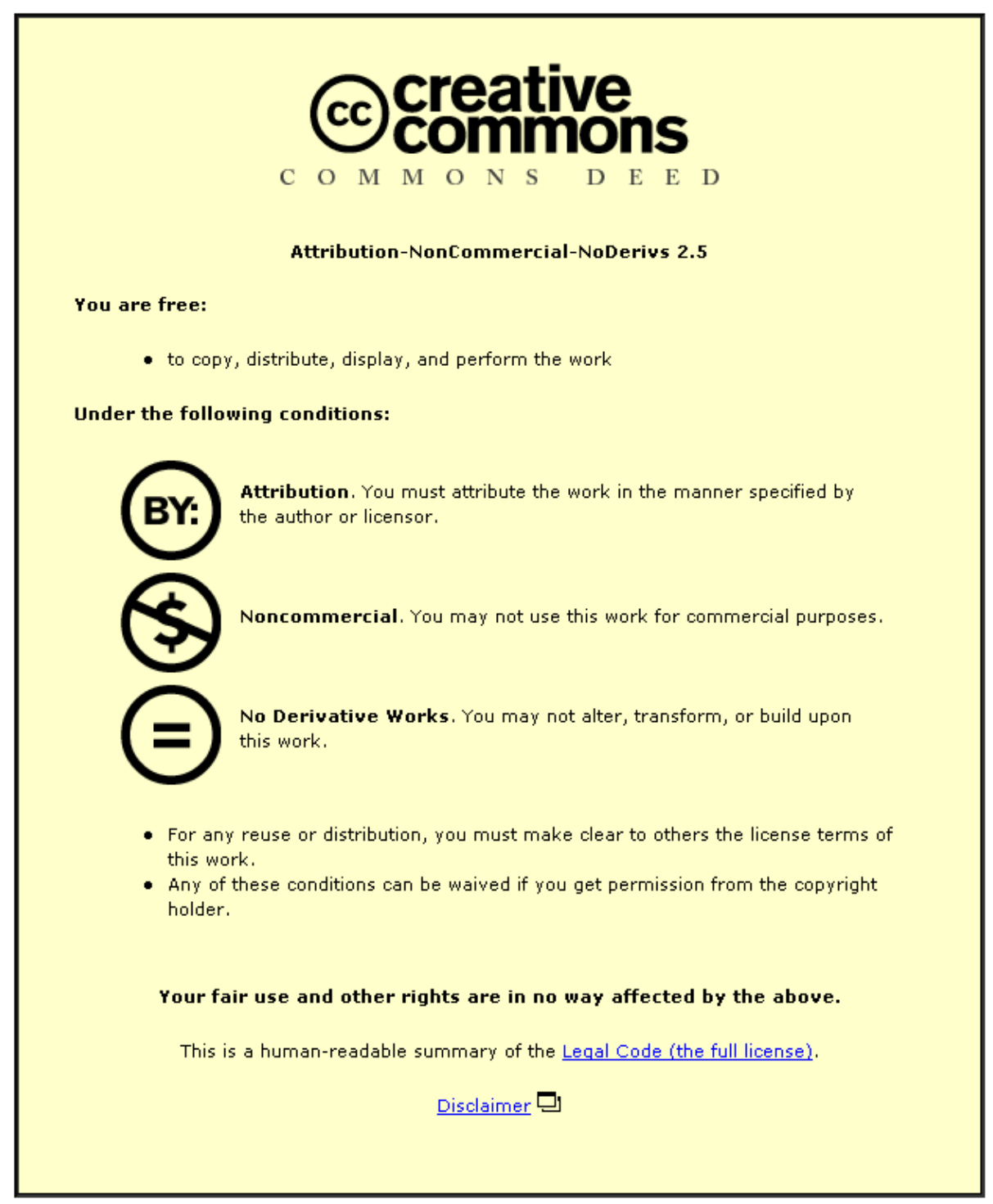

For the full text of this licence, please go to: http://creativecommons.org/licenses/by-nc-nd/2.5/ 


\section{3}

Anarchism, Individualism and Communism: William Morris’s Critique of Anarchocommunism

Ruth Kinna

Introduction

William Morris’s commitment to revolutionary socialism is now well established, but the nature of his politics, specifically his relationship to Marxism and anarchist thought, is still contested. Perhaps, as Mark Bevir has argued, the ideological label pinned to Morris’s socialism is of 'little importance' for as long as his political thought is described adequately. Nevertheless, the starting point for this essay is that thinking about the application of ideological descriptors is a useful exercise and one which sheds important light on Morris's socialism and the process of ideological formation in the late nineteenth-century socialist movement. Bevir is surely right when he says that 'ideologies are not mutually exclusive, reified entities' but 'overlapping traditions with ill-defined boundaries' $<x$ xen $^{1}</$ xen $>$ Yet the struggle to reify these boundaries in a messy political world is a dominant feature in the history of the Left and one in which Morris was not afraid to engage. Indeed, towards the end of his life he made a concerted attempt to draw an ideological boundary between his preferred form of revolutionary socialism and anarchism. This not only makes him an interesting subject for the analysis of Marxist-anarchist relations, it also raises questions about the adequacy of the familiar charge that anarchism is both inherently individualistic and, as a consequence, ill-equipped to develop a coherent approach to democratic decisionmaking. Morris defined his ideological position between 1883 and 1885 and called himself a communist. In 1890, when he withdrew from the Socialist League and established the 
Hammersmith Socialist Society he described this position negatively: neither state socialist nor anarchist. $<$ xen $>^{2}</$ xen $>$ In adopting this formulation Morris did not mean to suggest that he straddled these two ideological poles. Rather he wanted to indicate his independence from both. However, in 1893-1894 he repositioned himself once more, representing communism as a rejection of anarchism. His claim, that anarchists were individualists, was a recurrent charge in the non-anarchist socialist press, but Morris was an unusual critic of anarchism because he was sensitive to the different currents that ran through anarchist and individualist thought. Moreover, his late application of the individualist tag was extended to include anarchists with whom he had worked most closely: anarchist communists. Coming from him, the charge appears as an obvious reduction that grouped together a set of ideas that were based on very different, not always compatible, political, economic and ethical principles. The undiscriminating and angry tone of his critique can be explained by his rejection of the political violence of the late nineteenth century, a tactic that seemed all the more futile once Morris had acknowledged the failure of the anti-parliamentary revolutionary strategy he had adopted in the 1880s. He developed the theoretical justification for the critique in a discussion of the limits of freedom and individual-community relations. $<$ xen $>^{3}</$ xen $>$ This discussion drew on concepts of slavery, tyranny and mastership that he had elaborated in the 1880s. Morris's claim was that anarchism wrongly denied limits to freedom and that it was therefore socially disintegrative: individualist. The fatal flaw of anarchism was illustrated, he further suggested, by the inability of anarchists to show how individuals might enter into a process of decision-making and, therefore, to develop any practical socialist alternative. Unfortunately for Morris, this argument revealed that the ideological divide he sought to establish - between communism and anarchism - could be sustained only by his adoption of a model of decision-making that ran counter to his own radical principles of mastership and tyranny because it demanded the identification of democracy with the subordination of 
individual to class interests.

The argument is developed in three sections. The first discusses Morris's late critique of anarchist communism and his treatment of this strain of anarchism as a generic form. It examines his motivations and sets out the key concepts on which he later relied to develop his analysis of decision-making. The relationship between anarchism and individualism is discussed in the middle section, both in order to contextualise Morris's understanding of these terms and to demonstrate how his awareness of anarchist and individualist politics gave way to the narrower system of ideological classification. His attempt to demonstrate how the inherent individualism of anarcho-communism ruled against collective agreement is the subject of the concluding part. It should become clear that the conjunction of anarchism and individualism that Morris sought to cement is dubious and that the boundaries between socialist traditions are more porous than he wanted to admit.

Morris’s critique of anarchism

On 1 May 1893 leading members of the Social Democratic Federation, the Fabian Society and Morris’s Hammersmith Socialist Society issued the Manifesto of English Socialists. This document, to which Morris was a signatory, was intended to outline 'the main principles and broad strategy on which ... all Socialists may combine to act with vigour' and it called on socialists to 'sink their individual crochets in a business-like endeavour to realise in our own day that complete communization of industry for which the economic forms are ready and the minds of the people are almost prepared' ${ }^{\prime}<$ xen $>^{4}</$ xen $>$ Notwithstanding its apparent inclusiveness, the Manifesto specified the limits of socialist co-operation:

... we must repudiate both the doctrines and tactics of Anarchism. As Socialists we believe that those doctrines and tactics necessarily resulting from them, though advocated as revolutionary by men who are honest and single-minded, are really reactionary both in theory and practice, and tend to check the advance of our cause. 
Indeed, so far from hampering the freedom of the individual, as Anarchists hold it will, Socialism will foster that full freedom which Anarchism would inevitably destroy. $<$ xen $>^{5}</$ xen $>$

Morris’s willingness to put his name to the Manifesto was not entirely surprising: the deterioration of his relationship with the anarchists in the Socialist League, which eventually forced his withdrawal from the party and the editorship of Commonweal, the League's paper, helped explain the gradual but increasing hardening of his attitude. He had already voiced misgivings about anarchism in News From Nowhere and in the year following the publication of the Manifesto this light ridiculing turned into uncompromising rejection. In 1894 two important articles appeared. The first was an interview, 'A Socialist Poet on Bombs and Anarchism', published at the start of the year in Justice, the journal of the Social Democratic Federation. The second, an essay entitled 'Why I am a Communist', appeared in James Tochatti’s anarchist paper Liberty the following month. Morris made two claims: that anarchism was an individualist doctrine and that its individualism was reflected in the recent and unacceptable turn to political violence.

His critique of anarchist individualism focused on two points, what Stefan Collini identifies as its methodological and moral principles. These were often used to support a politics of individualism, but were not necessarily presupposed by it. $<$ xen $>^{6}</$ xen $>$ Morris's objection to methodological individualism was that it was impossible to make sense of individual behaviours by abstracting individuals from their social context. The moral principle, which he tied to it, was that that the communal bonds that he believed essential to individual flourishing, were wrongly represented by individualists as only so many potential constraints. Anarchism, he argued, embraced both ideas and the two articles that he published in 1894 advanced this case.

In Justice Morris argued: 'man is unthinkable outside society. Man cannot live or move 
outside it. This negation of society is the position taken up by the logical Anarchists $\ldots$. $<$ xen $>^{7}</$ xen $>$ In 'Why I am a Communist' he reiterated the point. One of the distinctive features of the communist position, he argued, is the conviction that 'mankind is not thinkable outside of Society' $<$ xen $>^{8}</$ xen $>$ In contrast, 'Anarchism, as a theory, negatives society, and puts man outside it’. Although Morris accepted that anarchists like Kropotkin, who he knew quite well, were not in fact 'against society altogether', $<$ xen $>{ }^{9}</$ xen $>$ having once granted this exception he refused to acknowledge that anarcho-communism described a coherent politics. This term, he argued, was a 'flat contradiction': 'In so far as they are Communists they must give up their Anarchism' because anarchism 'is purely destructive, purely negatory’. Comrades like Kropotkin who called themselves anarchists were deluded, Morris argued. They 'cannot be Anarchists in the true sense of the word'. $<$ xen ${ }^{10}</$ xen $>$ Morris's understanding of moral individualism was underpinned by the interrelated concepts of 'tyranny', 'slavery', ‘mastership’ and 'fellowship'. Perhaps ill-advisedly using tyranny to describe the nature of social existence, he reasoned that because individuals could not be understood in the abstract and must always be considered as members of particular communities, they were always necessarily constrained by social arrangements. Tyranny was thus an unavoidable feature of all social life. Naturally, Morris recognised that social tyranny could take different forms and that it was not necessarily empowering or benign. In other words, some social systems were also tyrannical. The distinction Morris made was between ‘true’ and ‘false’ or 'arbitrary’ society. Commercial society plainly fell in the latter category, since here social relations were based on class coercion, or what Morris called 'force' and ‘fraud’. In socialism, tyranny would assume ‘true’ form. This was the position Morris outlined in the Statement of Principles of the Hammersmith Socialist Society:

For here we must say that it is not the dissolution of society for which we strive, but its reintegration. The idea put forward by some who attack present society, of the 
complete independence of every individual, that is, for freedom without society, is not merely impossible of realization, but, when looked into, turns out to be inconceivable. $<$ xen ${ }^{11}</$ xen $>$

The goal of revolutionaries, Morris argued, was to rid society of slavery rather than tyranny, since when slavery was abolished tyranny's tyrannical features would also disappear. As Susan Buck-Morss notes 'slavery had become the root metaphor of Western political philosophy' by the eighteenth century, 'connoting everything that was evil about power relations' $<<$ xen $>^{12}</$ xen $>$ Morris appeared to follow this convention and defined slavery as a relation based on compulsion, rooted in nature and institutionalised in economic power. In nature, he argued, all life was enslaved by the necessity of labour. The stark choice was to work or perish. In human societies, nature’s compulsion was overlaid by secondary systems of enslavement. These could take different forms but Morris believed that each historical type reflected the attempt of a minority to escape the force of nature and the dictates of labour, and he argued that the differences between them were irrelevant to their classification. Bondslavery, feudalism and wage-labour were not moral equivalents but they all enabled the elite to live from the labour of others and stripped those charged with the burden of labour of effective choice in production. This group were thus doubly enslaved.

Morris applied the same reasoning to women, yet he argued that there was a difference between labour and the way that slavery operated in this context. Women were dependent on men as well as slaves to capitalism, and they were therefore triply enslaved. Even accepting that there was 'the closest of relations between the prostitution of the body in the streets and of the body in the workshops', $<$ xen $>^{13}</$ xen $>$ he concluded that the liberation of women required a social as well as an economic change: dependence on men in addition to the abolition of capitalism and, above all, the abolition of bourgeois marriage laws which enshrined the power relations that compelled women to prostitute themselves for the sake of 
economic security, controlling their reproduction in addition to their labour. Tyrannical societies (that is, those based on slavery) operated through mastership. In The Dream of John Ball, a story of the 1381 Peasants’ Revolt, Morris tells the eponymous hero of the story that

men shall yet have masters over them who have at hand many a law and custom for the behoof of masters, and being master can make yet more laws in the same behoof; and they shall suffer poor people to thrive just so long as their thriving shall profit the mastership and no longer. $<$ xen $>^{14}</$ xen $>$

Mastership blinded individuals to their exploitation by masking naked greed with false ideas of duty, natural hierarchy and political obligation. John Ball tells his listeners: 'sooth it is that the poor deemeth the rich to be other than he, and meet to be his master, as though, forsooth, the poor were come of Adam, and the rich of him that made Adam, that is God'. $<$ xen $>{ }^{15}</$ xen $>$ Yet in principle, Morris associated mastership with wilfulness and was more concerned with its location than its existence. As one of the fictional characters of his prose romances says: “ "So it is then the world over, that happy men are wilful and masterful." ' $<$ xen $>^{16}</$ xen $>$ The same idea is expressed by the fourteenth-century peasants. Morris observes how the artisans sing a song 'concerning the struggle against tyranny for the freedom of life ... of the life of a man doing his own will and not the will of another man commanding him for the commandment's sake'. $<$ xen $>^{17}</$ xen $>$ The promise of mastership was that it could be recovered by and devolved to individuals, so that instead of satisfying another's will each was able to realise their own. Structurally, this demanded economic equality (which Morris defined as a principle of distribution according to need), an end to both the artificial hierarchies that facilitated slavery and the compulsion that forced labour. Yet none of these conditions released individuals from the duties and obligations that unjust, tyrannical societies perverted. In just social conditions, these obligations and duties would 
persist.

In a future communist society, Morris anticipated duty and obligation transformed. As masters, individuals exercised their own will but they did so co-operatively or, as Morris put it, in fellowship. Although he did not pinpoint precisely what he meant by this concept, he captured the essence of the social relations he desired in his discussions of art. His principle assumption was that the democratisation of art in communism would free individuals by transforming work. $<$ xen $>^{18}</$ xen $>$ As artists, individuals would meet their essential needs by engaging in productive leisure. Working voluntarily, they would no longer perceive labour as compulsion but instead as pleasure. However, the freedom they experienced as artists would meet a communal as well as an individual need. As Morris explained to James Tochatti in 1894, in communism artists 'will work for the benefit of ... the whole people: whereas now they work for the masters, the rich class, that lives on the labour of others' ${ }^{\prime}<$ xen ${ }^{19}</$ xen $>$ Free to do what they willed, individuals would produce things that were thought to be 'beautiful and pleasant' and which they hoped would give pleasure to others. They would have full scope for creative expression - mastership - but would find meaning for their art in fellowship. In the true sense, Morris argued, art was impossible, except by means of the co-operation of labour that produces the ordinary wares of life; and that co-operation again they cannot have as long as the workmen are dependent on the will of a master. They must co-operate consciously and willingly for the expression of individual character and gifts which we call art. $<$ xen $>^{20}</$ xen $>$ While the theoretical weakness that Morris eventually identified in anarchism rested on the claim that individualism ruled against the possibility of co-operation and collective agreement, his late critique also fastened on what he considered to be the practical implications of the anarchists' individualist stance. His charge was that because anarchists failed to understand that individuality must issue from, or in tandem with co-operation, their 
individualism played itself out in violence. Evidence to support the charge was readily available. In the early 1890s a series of trials provided a platform for anarchists accused of committing a range of high-profile assassinations and bombings to justify the use of violence as a revolutionary tactic. In his interview for Justice, Morris referred to some of the more notorious characters involved, notably Ravachol and Vaillant. His complaint against them was two-fold: insofar as their acts involved the targeting of 'non-combatants' they were immoral and as a revolutionary strategy violence was futile. Quite a lot of anarchists including Kropotkin - agreed. Yet Morris appeared to draw the arguments together to suggest that the anarchists' lack of feasible alternative highlighted a lack of constraint that was implicit in their individualism.

His view was mediated by a longer reflection about the prospects for revolution. During the whole period of his active involvement in socialism (1883-1896) Morris’s expectations about revolution altered considerably and his relationship with anarchism varied in turn. His warmest relations with the anarchists coincided with a period of optimism in the mid- to late 1880s when he combined a commitment to 'making socialists' with a policy of antiparliamentarism, in preparation for the anticipated collapse of capitalism. His sympathies began to wane after 1887 when the disaster of Bloody Sunday (a mass demonstration in London's Trafalgar Square which met with extraordinary police violence, leaving three dead and hundreds injured) gave him a glimpse of the sheer might of the state's reactionary force. No longer sanguine about the willingness or capability of the workers to immediately confront or resist it, Morris became convinced that his efforts to make socialists through antiparliamentary activity were hopeless and that the strategy would likely end in disaster. By the early 1890s his criticisms of anarchism became more strident as he reluctantly reconciled himself to the idea that parliament offered the only available route to change. $<$ xen $>{ }^{21}</$ xen $>$ Having taken stock of the reality of class struggle, he tired of talk of revolution and felt that 
those who indulged in such arguments were deluded.

Morris's reassessment of revolution not only coincided with the wave of political violence explicitly associated with anarchism but, equally importantly, with its enthusiastic embrace by self-identifying anarchists in the League. At precisely the point that Morris accepted parliamentarism as the only available route to socialist change, some League anarchists found their inspiration in assassination and random killing and adopted a rhetoric of revolutionary violence that filled him with frustration and despair. Although he continued to offer financial support to former comrades who fell foul of the incitement laws and agent provocateurs, the co-operation he had once enjoyed with anarchists both in an out of the League as an antiparliamentarian gave way to a deep hostility. When James Tochatti first requested a statement of his politics in Liberty, Morris told him that he could not 'in conscience' allow his name to be 'attached' to an 'anarchist paper' because of the 'promiscuous slaughter' which anarchists had adopted as 'a means of converting people'. $<$ xen $>^{22}</$ xen $>$ The significance of this reappraisal was not missed by observers. One anonymous anarchist correspondent to Liberty wrote that Morris now counter-posed violence to political action as if there were no other possibility, a view that wrongly dismissed the revolutionary potential of 'trade combinations' and of waging precisely the kind of extra-parliamentary struggle that he outlined in the chapter 'how the change came' in News From Nowhere. $<$ xen $>^{23}</$ xen $>$ Having put his name to the Manifesto, Morris appeared to be persuaded that there were only two routes to socialism: parliament or terror. Even if the former was likely to lead to a type of socialism that he did not like, the refusal of all anarchists to accept it and the willingness of some to choose terror indicated the extent of their individualism. Only those who prioritised this concept above all others would fail to see the necessity of supporting the collective struggle or perform blatantly immoral acts that ran counter to ordinary political calculations. As individualists, Morris concluded, anarchists were not prone to violence as such, but to 
assertive and transgressive behaviours which might be expressed violently and which were at root, anti-social. Taking August Vaillant (the anarchist executed in 1894 for throwing a bomb into the French Chamber of Deputies) as his model, Morris linked individualism to vaingloriousness.

Prepared to sacrifice his life in order to gratify his vanity; he is a type of men [sic] you meet in all grades all professions. You and I have met some of them; even among artists and poets they are not unknown; men who would do, in their art, what they knew to be quite wrong and outrageous in order to gain notoriety rather than work honesty and well and remain in obscurity. $<$ xen $>^{24}</$ xen $>$

In Morris’s mind, anarchists like Vaillant were artists of a particular stripe. Failing to understand their social obligations and duties, they denied fellowship and so wrongly interpreted mastership as a principle of individual domination. Morris found another model of this brand of individualism in capitalism and in the experimentation of elite art where, what passed as creativity was increasingly driven by the desire to secure a niche in the market through notoriety: false claims to 'originality' fuelled by 'competition for the guineas of the Manchester patron' $<x$ xen $>^{25}</$ xen $>$ In this competitive environment 'everybody must at least pretend to be a master: for, look you, it no longer pays an artist to work hard to correct the faults which he himself cannot fail to recognize' $<$ xen $>^{26}</$ xen $>$ This analysis tapped into discussions of decadence, which as Regenia Gagnier shows, cut across late Victorian literary, political and scientific fields. $<$ xen $>^{27}</$ xen $>$ Although it was clear that individualism in the arts represented a different level of attention-seeking to assassination and terror, Morris was not alone in thinking that it came from the same root and that it expressed a similar anarchistic distain for social engagement, co-operation and mutual support as well as integrity and self-reflection.

To summarise: Morris’s attempt to classify all anarchists as individualist appeared to 
establish a clear ideological boundary between anarchism and communism. Violence was symptomatic of this division, but it was rooted in an understanding of individual-community relations that Morris derived from his concepts of fellowship, mastership and tyranny: a social condition of co-operative interdependence, supported by economic equality. Morris’s position was certainly clear, yet as an accurate description of ideological difference it was deeply flawed. The sweep of his late designation of anarchist thought was muddied by the complexity of political debate and the contestation of both of his central terms: 'anarchism' and 'individualism'. As will be seen below, these terms were used to describe free market anti-statism at one end of the spectrum and the anti-capitalist, anti-authoritarianism of Bakunin and Kropotkin at the other. Morris directed his critique at both, but his blanket rejection of anarchism assumed a questionable conflation that was belied by divisions within Victorian individualism and the anarchist movement itself.

Anarchisms and individualisms: from politics to ideology Individualism was a central term in late Victorian political debate and disagreements about the role of the state, in particular, were conceptualised in terms of its opposition to collectivism. $<$ xen $>^{28}</$ xen $>$ In late nineteenth- and early twentieth-century revolutionary socialist circles this debate took a distinctive turn. Revolutionaries also probed the rights and wrongs of state intervention - the delivery of welfare services, questions of individual rights and responsibilities - but looked as well at the state's class composition, its transformative potential, its ethical status and long-term existence. These interests affected the ways in which key terms of debate were couched. For example, socialists did not so much use collectivism as a synonym for socialism, as was the habit of anti-collectivists, but to describe a commitment to a principle of common ownership which could be interpreted either to mean centralised state ownership, decentralised communal and/or direct workers' control. The goal of revolution was usually described in other ways: socialism, communism, mutualism, 
anarchy, the co-operative commonwealth, and sometimes democratic socialism and, pejoratively, state socialism. Anarchists sometimes defined ‘collectivism' even more narrowly, to describe the principle of distribution according to work - or deeds - as opposed to the communist system of needs. Kropotkin's adoption of this usage enabled him to gloss over his differences with Bakunin while also disputing the claim that Marx was a communist. $<$ xen $>^{29}</$ xen $>$ Naturally, discussions conducted in the anti-collectivist circles had an impact on socialist debates and on perceptions of anarchism in particular. The pre-eminent position that Herbert Spencer occupied in the individualist camp meant that individualism was habitually associated with anti-statism, opening the way for anarchism to be linked to the defence of the free market, the economic doctrine that socialists typically mapped to individualist political theory. In the Liberty and Property Defence League (LPDL), a Spencerite organisation whose co-authored manifesto A Plea For Liberty was published in 1891, all these relationships were examined. Auberon Herbert, one of the group’s leading lights called himself a 'voluntaryist', a stance which combined resistance to the state, 'the great machine' as Herbert called it, and the 'many systems of State force' with recognition of the 'free and open market'. His political ideal was one which released the 'living energies of the free individuals' and left them free to combine in their own way, in their own groups, finding their own experience, setting before themselves their own hopes and desires, aiming only at such ends as they truly share in common, and ever as the foundation of it all, respecting deeply and religiously alike their own freedom, and the freedom of all others. $<$ xen $>^{30}</$ xen $>$ Herbert rejected the label anarchist because he supported a system of regulation to 'repress aggression or crime' $<$ xen $>{ }^{31}</$ xen $>$ but other members of the LPDL - notably J. H. Levy did not and in embracing it further blurred the boundaries between different anarchisms. Dividing anarchists into three camps - 'conservative', 'communist' and 'individualist' - he 
acknowledged that communism occupied the main ground of the movement, but argued that none of the factions could claim exclusive rights over its application. Moreover, the generic use of the term 'anarchist' did not worry him since he believed that there was an important family resemblance between these varieties. United in their opposition to 'coercive cooperation' or government - what he called socialism - anarchists differed only on the structural mechanisms required to achieve their aims: whether to maintain full rights of ownership, abolish property rights or allow property in use. $<$ xen $>^{32}</$ xen $>$ The secretary of the LPDL, Wordsworth Donnisthorpe, took yet another approach. At first resisting the label, he later identified himself as an anarchist because he believed that anti-statists were more interested in defending privilege by entrenching market advantage in monopoly than in genuinely expanding the sphere of liberty. According to Wendy McElroy, he was steered in this direction by Benjamin Tucker, having been for many years a correspondent to Liberty and the paper's most frequent British contributor. $<$ xen $>^{33}</$ xen $>$

Outside the LPDL, anarchist opinion about the proper designation of anti-collectivist individualism was similarly divided. For Max Nettlau, an associate of Kropotkin, Herbert’s voluntaryism was 'humane and vigorously anti-statist' but ultimately dilettante and not 'anarchist'. $<$ xen $>{ }^{34}</$ xen $>$ In contrast, Tucker described Herbert as a true anarchist. $<$ xen $>^{35}</$ xen $>$ Victor Yarros, an associate of Tucker, made the same claims for Levy. $<$ xen $>^{36}</$ xen $>$ These responses broadly mapped to sub-divisions between so-called individualist, egoist, mutualist and communist principles. As a rule of thumb, anarchists who put themselves in one of the first two groups tended to be more receptive to anti-collectivist individualism than mutualists or communists. Yet, as discussions within and between these groups show, anarchist conceptions of individualism were far more complex and messy. For example, notwithstanding the common ground that anarchist individualists sometimes found with anti-collectivists, anarcho-communists did not reject individualism out of hand. Indeed, 
while Kropotkin felt that Tucker's Spencerite leanings ultimately pointed to the defence of a minimal state, he endorsed key tenets of his anti-statist critique. On Spencer’s death, Freedom, the anarchist paper Kropotkin helped establish, feted Spencer as 'the greatest philosopher of the nineteenth century'. His two virtues were that he had 'vigorously shaken the foundation stone of the idea of God, or authority and of superstition on which the power and privileges of the rich oppressors are based' and that he had 'denounced the State as a pernicious establishment bequeathed to us by the barbarians and strengthened by those idle and oppressing social classes living on the labour of the people' $<$ xen $>^{37}</$ xen $>$ Kropotkin offered another appreciation, highlighting his common commitment to Spencer’s rationalism, love of naturalistic science and celebration of the idea that 'the welfare of the individual' was the single most important postulate of the social and physical sciences. $<$ xen $>^{38}</$ xen $>$ Spencer had shown that individuals had a capacity to reason, co-operate and develop social behaviours without compulsion and without recourse to religion or other metaphysical speculation. In this he had followed the tradition established by Proudhon. Anarchists, Kropotkin argued, endorsed both his analytical approach and his anti-statism.

Anarchist communists were intolerant of anti-collectivist economics, however, and parted company equally with anti-collectivists and anarchist individualists on questions of property and exchange. Nettlau, together with another of Kropotkin's comrades, Varlaam Tcherkesov, argued that these issues were the real determinants of individualist and non-individualist doctrines. Insofar as Nettlau and Tcherkesov’s arguments treated varieties of anarchism as mere 'economic forms' their understanding bore some relation to Levy's. $<$ xen ${ }^{39}</$ xen $>$ The difference was that Levy’s Spencerite leanings led him to identify all anarchists (including communist) as individualists and anti-socialist, whereas Tcherkesov changed the ideological poles of debate to argue that individualism represented a deviation from a socialist-anarchist norm. By his reckoning, the division between anarchists and individualists was marked by the 
anarchist's rejection of private ownership and the market. Thus placing '[Max] Sterner’ [sic] in the same category as Spencer, he dismissed both as 'bourgeois' $<$ xen $>{ }^{40}</$ xen $>$ In 1893 Freedom published a full statement of this view:

Communist anarchists claim as the basis of the new social order common property, whereas Individualists defend private property as the necessary foundation of society ... Nor is that the only difference between Communist and Individualist Anarchists. Communist Anarchists maintain that the necessary accompaniment of private property is government; a government of some kind, whether a parliamentary one, or a sort of East India Company, or a Pinkerton Police Force salaried by the capitalists. And as to the 'voluntary' taxation and other 'voluntary' things advocated by Individualists, we fail to see how, in a society based on private property and individual competition, the people who ‘voluntarily' submit to a tax could be prevented from shifting the burden on to their neighbours; or how those who join in a Defence Association would be prevented from using this organized force against others than themselves. $<$ xen $>^{41}</$ xen $>$

Tying the anarchism to a particular politics rather than an economic form, mutualists challenged Tcherkesov's anarchist-individualist dichotomy. Mutualism, they argued, was not a mere economic system, even if liberty of production, or the right of producers to determine how goods were to be distributed and disposed of, was central to it. $<$ xen $>^{42}</$ xen $>$ Importantly, mutualism differed from the anti-collectivist individualism associated with Herbert and Spencer, because it did not justify unlimited accumulation or authority through private property. $<$ xen $>^{43}</$ xen $>$ Some communists accepted the ethical distinction that the mutualists sought to make between their own position and unqualified anti-statism. As a correspondent to Freedom noted, plain individualism was Lockean: it described 'the right of the individual to appropriate the result of other people's labor over and above what he pays 
them in wages, though he generally has to share this surplus according to agreement with the usurer, landlord and government'.$<$ xen $>^{44}</$ xen $>$ Mutualism, by contrast, was egalitarian and it did not allow such appropriations. Treating mutualist claims seriously, these anarchists nevertheless criticised mutualists for calling themselves individualists because it wrongly implied ‘a tautology between Individualism and Anarchism' and misleadingly conflated an agreement (between communists and mutualists) about ethics with a disagreement about the operation of markets. $<$ xen $>{ }^{45}</$ xen $>$ Rejecting this implication, the anarcho-communists argued that they were as committed to individual freedom as the mutualists were and that communism was the only economic system capable of securing the liberties that both groups of anarchists cherished. Kropotkin made a similar point in a discussion of Proudhon and Stirner, but introduced a modification to the terms of debate. Proudhon, Kropotkin argued, understood correctly that moral conscience, by which he meant a conception of justice and equality, had a basis in social life. Stirner argued that morality existed only by convention and wrongly concluded that it was necessarily rooted in authority. $<$ xen $>^{46}</$ xen $>$ On this reading, mutualism described a system of anarchist ethics based on the principle of individuality; egoism, by contrast, was an individualist doctrine which sanctioned selfishness in the name of self-expression. $<$ xen $>^{47}</$ xen $>$

These were a complex set of debates and because they involved a range of individuals who assumed a number of different theoretical perspectives, there was little consensus about where or how to draw the lines of ideological division. Perhaps not surprisingly, therefore, outside observers sometimes simply passed over the complexity of anarchist politics and failed to acknowledge the different ways in which the relationship between anarchism and individualism was understood. For example, in a sweeping critique of a priori political philosophy, T. H. Huxley identified two important trends in the history of European thought: regimentation and anarchy. The first was defined by the view that 'the blessings of peace' 
required the surrender of rights to authority. In the modern period Hobbes stood at its head. The second, anarchy, typically treated individuals as 'highly intelligent and respectable persons, "living together according to reason, without a common superior on earth, with authority to judge between them" ',$<$ xen $>^{48}</$ xen $>$ This was the tradition of Locke. On this system of classification Auberon Herbert - who rejected the label - was as much an anarchist as Levy who was willing to accept it or, as Huxley in fact suggested, as Stirner and Bakunin. $<$ xen $>{ }^{49}</$ xen $>$ Non-anarchist socialist critics tended to treat the divisions within the anarchist movement in an equally cavalier manner and even more mischievously. In 1893 Freedom noted that social democrats usually 'disposed' of anarchism in one of three ways. One was to claim that it was 'too perfect an ideal' and utopian. Another was to suggest that anarchy was identical to the social democratic vision and that 'anarchism and anarchy' were just 'bad neologisms'. The third was to argue that anarchism was 'a return to barbarism ... a new form of the old and discredited laissez-faire doctrine', 'reactionary' to boot. $<$ xen $>^{50}</$ xen $>$ This last claim touched directly on the nature of anarchist individualism and it became one of the dominant themes in social democratic writing, not least because it was taken up at the turn of the century by Lenin. $<$ xen $>^{51}</$ xen $>$ Writing in 1896 , William Liebkecht advanced precisely this case. On account of the influence that Stirner had exercised on the anti-socialist Eugene Richter (whose 1891 satire Pictures of a Socialistic Future mocked German social democracy as a hopelessly inefficient and frighteningly utopian tyranny), Liebkecht traced the origins of anarchism to Stirner and thus denounced it as an individualist doctrine. $<$ xen $>^{52}</$ xen $>$ While Stirner's egoism was indeed open to individual property ownership, the elision of egoism with limited state doctrines and the extension of this combination to anarchism in general was - as Tcherkesov protested - highly misleading. Still, Liebkneckt argued:

There is, in fact, nothing in common between Anarchism and Socialism. Anarchism 
... has individualism for its basis; that is, the same principle on which capitalist society rests, and therefore it is essentially reactionary, however hysterical may be its shrieks of revolution. $<$ xen $>^{53}</$ xen $>$

How did Morris approach these debates? The answer is that the view he expressed in 18931894 was based on a classification equally reductive as Huxley’s and Liebkneckt’s. Yet it was unusual because it was also based on both a familiarity with the anarchist movement (that Huxley lacked) and a much closer and sympathetic involvement with anarchist politics than Liebkneckt had ever enjoyed.

Morris’s diary for 1887 distinguished three groups. The first were what he called the 'orthodox’ anarchists who met at Cleveland Hall and he identified Victor Dave - with whom he and Belfort Bax co-wrote their history of the Paris Commune - as their 'leading spirit'. The second were the anarchists of the Autonomy group and the third the Freedom group organised around Kropotkin and Charlotte Wilson. Morris was aware of these groups’ different constituencies. He noted, for example, that Dave’s ‘orthodox’ anarchists were fervent internationalists, largely French and German speaking refugees. A newspaper cutting from the Daily News pasted into his diary described Charlotte Wilson as a 'South Kensington or British Museum art-student' type, an 'aesthete with views', capturing an image of the Freedom group that was usually painted in less polite terms by the anarchists of the Socialist League. $<$ xen $>^{54}</$ xen $>$

Apart from noting their different meeting places and memberships, Morris seemed unsure of the issues that divided these groups. For example, he admitted ignorance of the grounds of the 'quarrel' - a spying scandal - which divided Dave’s anarchists from the Autonomy group, though later becoming involved in the affair, he designated the latter as 'unrespectable'. $<$ xen $>^{55}</$ xen $>$ Yet, as Florence Boos notes, Morris appreciated that there were significant divisions between ‘orthodox Anarchists', ‘collectivists’ and Kropotkin’s 
anarcho-communists. $<$ xen $>^{56}</$ xen $>$ Moreover, he identified the distinctively communist position with the rejection of government, of parliamentarism and the characterisation of bourgeois politics as a condition of war - a most tyrannous tyranny. What Morris called the ‘anarchical’ tendencies of Charlotte Wilson’s ‘Utopian Anarchist Superstition’ referred, additionally, to the communists' unwavering faith in the latent power of spontaneous grass roots resistance, a faith which he did not share. $<$ xen $>^{57}</$ xen $>$

Morris's observations of the anarchist movement hardly touched on the theoretical issues discussed in the anarchist press, but he was certainly familiar with the anti-collectivism of the LPDL. The text of a speech by Wordsworth Donnisthorpe, published in Henry Seymour's paper The Anarchist, earned a scornful review in Commonweal in 1887. $<$ xen $>^{58}</$ xen $>$ Donnisthorpe’s critical dissection of the Socialist Catechism by Morris’s friend J. L. Joynes might well have influenced his judgement, but either way Morris described the speech as an example of the 'pessimistic paradoxical exercises which are a disease of the period, and whose aim would seem to be the destruction of the language'. $<$ xen ${ }^{59}<$ xen $>$ Morris's judgements of Auberon Herbert were hardly warmer. He had worked with Herbert in the Eastern Question Association in the 1870s, and thereafter followed debates about 'voluntaryism' in the liberal reviews, but this personal association failed to encourage an appreciation of his ideas. The critique Grant Allen presented in the essay 'Individualism and Socialism' was too tame for Morris, but he agreed with Allen that the LPDL's defence of property in use would result in the very monopoly that undercut the equal enjoyment of individual liberty the group championed. $<$ xen $>^{60}</$ xen $>$ As Morris put it: by supporting a principle of distribution according to deed, these anarchists 'wished to abolish organised monopoly but supported unorganised monopoly, or the rule of the strongest individual ... upholding ... private property with no association' $<<$ xen $>{ }^{61}</$ xen $>$ However confusing Morris found the internal politics of the anarchist movement, he was 
certainly familiar with some of the issues that divided anarchist communists from limitedstate anti-collectivists. Nevertheless, in his late critique of anarchism he subordinated these differences to capture both groups under the common principle of anti-authoritarianism. This approach to anarchism was well rehearsed in the non-anarchist socialist press, though Freedom's commentary on social democratic objections to anarchism overlooked it. For example, finding agreement neither in 'object, policy, nor methods' with the anarchists, Justice argued that the anarchist, 'will have no authority on any account' and that 'the SocialDemocrat believes that a certain amount of authority will always be necessary'.$<$ xen $>{ }^{62}</$ xen $>$ Anarchist anti-authoritarianism was also central to Engels' critique and, just as Liebkneckt used Stirner to link laissez-faire economics to anarchism, he drew on the same source to reveal the chaotic destructiveness of anarchist doctrines. Identifying Bakunin as the transmitter of 'Stirnerian “rebellion”' he jibed: 'the anarchists have all become "unique ones", so unique that no two of them can agree with each other' $<$ xen $>^{63}</$ xen $>$ Morris arrived at his position by a different route, fastening on collective agreement rather than abstract authority, but his claims were similar. He attempted to show that anarchist moral individualism rendered agreement in socialism impossible. His discussion drew back to the concepts he had elaborated in the 1880s: social tyranny, slavery and fellowship. Rejecting 'social tyranny', he contended, anarchists also denied fellowship, leaving individuals exposed to new forms of slavery, rooted in the unconfined principle of individual mastership. The difficulty of the charge was that it ran counter to a process of decision-making that Morris also supported, suggesting that the ideological reduction that he had distilled from his engagement with anarchist politics was perhaps faulty. Communism, anarchism and democracy Accusing the anarchists of being 'somewhat authoritative' on the issue, Morris argued that the individualism of the anarcho-communists was expressed through their rejection of 
collective agreement. $<$ xen $>^{64}</$ xen $>$ His starting point was that anarchists opposed agreement on the grounds that it gave power to majorities and was therefore coercive. For Morris, this argument was self-defeating. To illustrate why, he imagined a dispute about the building of a bridge. Should opinion be divided, he asked: 'What is to be done? Which party is to give way?' The anarchist answer, Morris thought, was to 'say it must not be carried by a majority'; Morris responded, 'in that case, then, it must be carried by a minority'. $<$ xen $>^{65}</$ xen $>$ The illogicality of the anarchist position pointed to an important theoretical principle: anarchists prioritised the rights of individuals over all forms of collective power.

Failing to recognise that equal freedom necessarily involved a coercive limit on the liberty of all, anarchists not only tied themselves in knots on the question of majoritarianism, they also committed themselves to the negative moral individualism that genuine communism Morris's doctrine - rejected. To the anarcho-communist readers of the Commonweal Morris argued that 'if freedom from authority means the assertion of the advisability or possibility of an individual man doing what he pleases always and under all circumstances, this is an absolute negation of society'. $<$ xen $>^{66}</$ xen $>$ No matter how much these anarchists openly disagreed with the 'voluntaryists' on questions of economics, they shared the same moral outlook. $<$ xen ${ }^{67}</$ xen $>$

The strength of Morris's conclusion lay in his claim that the anarcho-communists in fact understood authority as he suggested. Yet as the debates about individualism make clear, this argument was difficult to sustain. Admittedly, the clearest statements of anarchist-communist ethics appeared only after Morris had died. However it was clear from discussions in Freedom that anarcho-communists were extremely wary of non-communist anarchist doctrines and their impact on individual-community relations. Two particular examples were that mutualism failed to provide adequate safeguards to protect the egalitarian relations it 
espoused and that egoism gave free reign to individual competition. Morris expressed precisely the same worry about 'voluntaryism' and the individualism of the LPDL. More tellingly, Morris’s further explorations of democracy suggested that the fault line that he identified between communism and anarcho-communism was not based on the presumed incompatibility of anti-authoritarianism with unrestrained individual freedom, at all. Indeed, he located the problem of individualism in the tension between anti-authoritarianism and class interest. This argument secured the ideological division he wanted to cement, but it did not sit easily with the model of decision-making that he presented in his utopian romance, News From Nowhere.

Morris opened up the gap in the debate in his letter to the readers of Commonweal where he attempted to show how anarchist defences of liberty conflicted with the idea of a common good. He imagined two scenarios: one where the long-term stability of society was threatened by the rise of a tyrannous interest, for example, the attempt to reintroduce some form of slavery (like monopoly), and a second, short term dispute where opinions about a particular policy diverged. Both scenarios, he argued, legitimised coercion, but the legitimate tyranny assumed different forms. The first case, the threat of new enslavement, convinced Morris that there was a need for an organisation or a 'central body', at least for a temporary period, to enforce commitments to socialist principles. $<$ xen $>^{68}</$ xen $>$ The second dispute - the policy disagreement - did not demand this kind of regulatory body, but resolution depended on observance of socialist principles, or an idea of collective good. To illustrate, Morris imagined how a proposal to cut down 'all the timber in England' and turn the 'country into ... a market-garden under glass’ might be challenged. Opponents, he suggested, might prefer the landscape to remain wild and to preserve its natural beauty. $<$ xen $>^{69}</$ xen $>$ However, if the majority backed the proposal, it was only right that the imagined objectors (Morris put himself among them) subordinate their own interests to the general interest of the community. 
No matter how significant their differences might be - and the example Morris chose was designed to highlight how divisive he felt the issue was - the minority would 'give up the lesser for the greater' $<$ xen $>^{70}</$ xen $>$

On this account, Morris perceived communism to be anti-anarchist in two ways. On the one hand, the imagined central body institutionalised the social tyranny on which socialism depended, and on the other it gave priority to majority over minority or individual interests. Yet in 1894 he drew still further from anarchist thinking by adopting a position which relied on the recognition of a universal interest, not just the priority of the numeric majority. The pluralism which explained the policy disagreements that socialists were likely to face was now denied. Majority rule, he argued, 'is only harmful where there is conflict of interest'. $<$ xen $>^{71}</$ xen $>$ In socialism, 'there would be no opposition of interests, but only divergences of opinion' because the 'struggles between opposing interests for ... mastery', that were part and parcel of the existing parliamentary system, would be a thing of the past. $<$ xen $>^{72}<$ xen $>$ Morris's argument was consistent with his earlier rejection of representative democracy as a system of class rule, $<$ xen $>^{73}</$ xen $>$ but it suggested that majorities could never injure minorities once class divisions based on private ownership had been abolished. As Morris put it, 'community cannot compel the community' $<$ xen $>^{74}</$ xen $>$ This very Rousseauean view meant that individuals would be expected to identify with a higher authority, even while their opinions were being trampled on or ignored. $<$ xen $>{ }^{75}</$ xen $>$ Morris's unqualified defence of simple majoritarianism, let alone his assumption of universal class interest certainly put him at odds with a good proportion of anarchists, communists and individualists alike. $<$ xen $>^{76}</$ xen $>$ He was probably right to think that his proposal for a central defensive body would alarm all sorts of anarchists, ever mindful of the potential for the state's reconstitution. However, his claim the anarchist rejection of 'the tyranny of society' meant 'that every man should be quite independent of every other' $<$ xen ${ }^{77}</$ xen $>$ - 
as he phrased the critique in News From Nowhere - wrongly assumed that the rejection of these two models of decision-making exhausted the possibilities of radical democracy. This assumption was faulty because it overlooked the possibility of stepping between the tyranny of class interest and moral individualism, even though his own work contained an outline model of a non-tyrannous democratic system. Indeed, he fleshed out the point in News From Nowhere, where he again discussed the building of a bridge. $<$ xen $>^{78}</$ xen $>$ In his second hypothetical context, disagreements about the proposal are resolved through dialogue and a continuous process of direct, open balloting, neither by the submission of the minority to majority interests, nor by the recognition of the common good. In this picture of communism, agreement is reached through a deliberative process, supported by ordinary tyranny, capable of determining policy outcomes through the resolution rather than the subordination of differences. Morris fleshed out a similar process of consensual and deliberative debate in Commonweal. Assuming that ‘a dozen thoughtful men’ would have 'twelve different opinions' on 'any subject which is not a dry matter of fact', he argued that the group would negotiate a compromise to 'get their business done'. Morris described the 'common rule of conduct' that underpinned this process as a 'common bond' of 'authority'. In this context, however, 'authority' referred only to the background concept of tyranny, which he believed essential to any society, not the positive commitment to the common good - or class interest - that he subsequently adopted to distinguish his brand of communism from the individualism of the anarchists. $<$ xen $>^{79}</$ xen $>$

Having developed a model of decision-making which assumed that individuals might reach voluntary agreement through open discussion and consensus, Morris shifted his position when it came to distinguishing communism from anarchism. When it came to pinpointing the anarchism's ideological distinctiveness, agreement appeared to require more than the observance of moral norms and respect for individual autonomy (tyranny and mastership), 
which were the only conditions for consensus. In addition, it demanded the enforcement of majority rule (the relocation of mastership from individuals to the group) or, even more stringently, the recognition of a universal interest (the institutionalisation of mastership as an abstract idea). The elision of ordinary tyranny with majoritarianism substantiated Morris’s claim that anarchists were individualists, but the integrity of his consensual alternative was the price he paid.

One way of thinking about the alternatives Morris explored is to return to his understanding of mastery and art. His conception of anarchist anti-authoritarianism pointed to egotism, or a form of competitive, vain-glorious mastership which was consciously transgressive. Against this, he posited a defence of majoritarianism and universal interest. This mapped onto an idea of mastership which subordinated the interests of individual artists to the well-being of the community. A third possibility, one that he sidelined in his late critique of anarchism, was outlined in News From Nowhere. It suggested that creativity was primary but that the pleasure artists derived from their production was linked to its reception in the wider community. This assumed the existence of social tyranny, but one that was shaped by the expression of individual wills.

\section{Conclusion}

Morris's rejection of anarchism was fuelled by his frustrations with the Socialist League and the political violence of the early 1890s. It can be explained by the refusal to accept compromise on parliamenatary action - and perhaps the discomfort Morris felt in adopting a strategy that he knew to be flawed. His concerns about anarchist individualism were informed by principles of fellowship, mastership and tyranny which derived from deeply-held convictions about social relations in communism, but his critique depended on reductive ideological labelling which smothered the politics of the anarchist movement. Morris’s critique of anarchist individualism succeeded when couched in terms of 'anti- 
authoritarianism', but the costs of success were high: his discussion of decision-making and collective agreement was not easily reconciled with the idea of mastership he sought to defend. Anarchists might have found aspects of Morris’s communism troubling. But his attempts to dismiss anarchism as individualistic by showing that it was wholly incompatible with it, failed.

Acknowledgement

Thanks to Alex Prichard for repeated attempts to bring clarity to the argument.

$<$ fn-group type=“endnotes” $>$

$<$ en $><$ label $>1<$ label $>$ Mark Bevir, 'William Morris: The Modern Self, Art and Politics', History of European Ideas 24 (1998), 176.</en>

$<$ en $><$ label $>2<$ label $>$ William Morris, Statement of Principles of the Hammersmith Socialist Society, (London: Kelmscott Press, 1890), p. 6.</en>

$<$ en $><$ label $>3<$ label $>$ On Morris's divergence from Kropotkin on this issue see 'Morris, Anti-statism and Anarchy', in Peter Faulkner and Peter Preston (eds), William Morris:

Centenary Essays (Exeter: University of Exeter Press, 1999), pp. 215-228.</en> $<$ en $><$ label $>4<$ /label $>$ Manifesto of English Socialists, (London: Twentieth Century Press, 1893), p. $8 .</$ en $>$

$<$ en $><$ label $>5<$ label $>$ Manifesto, p. $5 .<$ en $>$

$<$ en $><$ label $>6<$ /label $>$ Stefan Collini, Liberalism and Sociology: L.T. Hobhouse and Political Argument in England 1880-1914, (Cambridge: Cambridge University Press, 1983), p.

16. $</$ en $>$

$<$ en $><$ label $>7</$ label $>$ William Morris, 'A Socialist Poet on Bombs and Anarchism: An Interview with William Morris’, Justice (27 January 1894), p. 6.</en> $<$ en $><$ label $>$ 8</label $>$ William Morris, 'Why I Am A Communist', Liberty (February 1894), pp. $13-15 .</$ en $>$ 
$<$ en $><$ label $>9<$ label $>$ Morris, 'Socialist Poet' $<<$ en $>$

$<$ en $><$ label $>10</$ label $>$ Ibid. $</$ en $>$

$<$ en $><$ label $>11</$ label $>$ Morris, Statement of Principles, p. 5. $</$ en $>$

$<$ en $><$ label $>12<$ label $>$ Susan Buck-Morss, 'Hegel and Haiti', Critical Inquiry 26 (2000),

821. $</$ en $>$

$<$ en $><$ label $>13<$ /label $>$ William Morris, Journalism: Contributions to Commonweal 1885-

1890, Nicholas Salmon (ed.) (Bristol: Thoemmes press, 1996), p. 27.</en>

$<$ en $><$ label $>14<$ label $>$ William Morris, 'The Dream of John Ball', in A. L. Morton (ed.), Three Works by William Morris (London: Lawrence \& Wishart, 1986), pp. 94-95.</en> $<$ en $><$ label $>15<$ label $>$ Morris, John Ball, p. 56.</en $>$

$<$ en $><$ label $>16<$ /label $>$ William Morris, The Story of the Glittering Plain (Bristol: Thoemmes Press, 1996), p. 322.</en>

$<$ en $><$ label $>17<$ label $>$ Morris, John Ball, p. 45.</en $>$

$<$ en $><$ label $>18</$ label $>$ For a recent discussion see Laurence Davis, 'Everyone an Artist: Art, Labour, Anarchy and Utopia', in Laurence Davis and Ruth Kinna (eds), Anarchism and Utopianism (Manchester: Manchester University Press, 2009), pp. 73-98.</en> $<$ en $><$ label $>19<$ /label $>$ Norman Kelvin (ed.), The Collected Letters of William Morris, vol. IV: 1893-1896 (New Jersey: Princeton University Press, 1996), p. 209.</en> $<$ en $><$ label $>20</$ label $>$ William Morris, Political Writings: Contributions to Justice and Commonweal, Nicholas Salmon (ed.) (Bristol: Thoemmes Press, 1994), p. 397.</en> $<$ en $><$ label $>21<$ label $>$ This shift is sometimes interpreted as a principled reversal of his earlier position, but can be explained as a pragmatic response to his disappointment with the failure of the League and his perception that workers were more interested in electoral power and welfare reform than revolution and the realisation of communism in the society of art. In 1895 Morris wrote that while he saw the 'necessity' of the 'political side' of the struggle, this 
was still an element with which he could not work. Norman Kelvin (ed.), The Collected Letters of William Morris, vol. IV: 1893-1896, (New Jersey: Princeton University Press, 1996), p. 285.</en>

$<$ en $><$ label $>22<$ label $>$ Letters IV, p. 113. $<$ en $>$

$<$ en $><$ label $>23</$ label $>$ Morris, Liberty, p. 18.</en $>$

$<$ en $><$ label $>24</$ label $>$ Morris, 'Socialist Poet'. $<$ /en $>$

$<$ en $><$ label $>25<$ label $>$ Morris, Political Writings, p. 37.</en $>$

$<$ en $><$ label $>26</$ label $>$ Ibid., pp. 37-38. $<$ en $>$

$<$ en $><$ label $>27<$ label $>$ Regina Gagnier, Individualism, Decadence and Globalization

(London: Palgrave/Macmillan, 2010), p. 2.</en>

$<$ en $><$ label $>28</$ label $>$ Collini, Liberalism and Sociology, pp. 14-15.</en $>$

$<$ en $><$ label $>$ 29</label $>$ Peter Kropotkin, in R. Baldwin, (ed.), Kropotkin’s Revolutionary

Pamphlets (New York: Dover, 1970), pp. 166, 295.</en>

$<$ en $><$ label $>30<$ /label $>$ Auberon Herbert, The Voluntaryist Creed: Being the Herbert Spencer Lecture Delivered at Oxford, June 7, 1906 (London: Henry Frowde, 1908), pp. 6-7. http://files.libertyfund.org/files/1026/0545_Bk.pdf (access 17 September 2010].</en> $<$ en $><$ label $>31<$ label $>$ See C. Tame, 'The Libertarian Tradition no. 1: Auberon Herbert', Free Life, The Journal of the Libertarian Alliance, 1/2 (1980), 2; E. Mack, 'Voluntaryism: The Political Thought of Auberon Herbert', Journal of Libertarian Studies, 2/4 (1978), 306; Wendy McElroy, The Debates of Liberty: An Overview of Individualist Anarchism, 18811908 (Lanham, Boulder, New York, Oxford: Lexington Books, 2003), p. 33.</en> $<$ en $><$ label $>32</$ label $>$ J. Levy, Appendix to Auberon Herbert, Taxation and Anarchism: A Discussion between the Hon. Auberon Herbert and J.H. Levy (London: Personal Rights Association, 1912). http://app.libraryofliberty.org/?option=com_staticxt\&staticfile=show.php\%3Ftitle=2257\&cha 
pter=212934\&layout=html\&Itemid=27 (access 17 October 2010].</en $>$

$<$ en $><$ label $>33</$ label $>$ McElroy, Debates of Liberty, pp. 7, 164.</en>

$<$ en $><$ label $>34<$ label $>$ Max Nettlau, A Short History of Anarchism, ed. H. M. Becker, trans.

I. P. Isca (London: Freedom Press, 1996), p. 40.</en>

$<$ en $><$ label $>35</$ label $>$ Mack, 'Voluntaryism', p. 306. $<$ /en $>* * *$

$<$ en $><$ label $>36</$ label $>$ McElroy, Debates of Liberty, p. 164. $</$ en $>$

$<$ en $><$ label $>37<$ label $>$ Freedom, January 1904. $<$ /en $>$

$<$ en $><$ label $>38<$ /label $>$ Peter Kropotkin, Freedom, April 1893.</en $>$

$<$ en $><$ label $>39<$ label $>$ Freedom, July 1895. $</$ en $>$

$<$ en $><$ label $>40<$ label $>$ Varlaam Tcherkesov, 'Socialism or Democracy', Supplement to

Freedom, June 1895.</en>

$<$ en $><$ label $>41<$ label $>$ Freedom, July 1893. $<$ /en $>$

$<$ en $><$ label $>42</$ label $>$ Freedom, June 1895. $<$ /en $>$

$<$ en $><$ label $>43<$ label $>$ Mutualists distinguished between property and possession and argued that the former, anything more than ones tools, personal possessions and dwelling, must always be co-operatively organised and co-ordinated.</en $>$

$<$ en $><$ label $>44<$ label $>$ Freedom, July 1895. $<$ /en $>$

$<$ en $><$ label $>45</$ label $>$ Ibid. $</$ en $>$

$<$ en $><$ label $>46<$ label $>$ Kropotkin, Revolutionary Pamphlets, p. 297; Peter Kropotkin, Ethics:

Origin and Development, trans. Louis S. Friedland and J. R. Piroshnikoff (Montreal/New

York: Black Rose, 1992), pp. 269-270, 338.</en>

$<$ en $><$ label $>47</$ label $>$ Kropotkin, Revolutionary Pamphlets, p. 172. $<$ /en $>$

$<$ en $><$ label $>48<$ /label $>$ T.H. Huxley, 'Government: Anarchy or Regimentation’ (1890), in

Collected Essays, http://aleph0.clarku.edu/huxley/CE1/G-AR.html (access 17 October

2010].</en> 
$<$ en $><$ label $>49</$ label $>$ Ibid. $</$ en $>$

$<$ en $><$ label $>50<$ label $>$ Freedom, July 1893.</en $>$

$<$ en $><$ label $>51<$ label $>$ V.I. Lenin, 'Anarchism and Socialism', in Marx, Engels, Lenin:

Anarchism and Anarcho-Syndicalism (Moscow: Progress Publishers, 1972), pp. 185-

186. $</$ en $>$

$<$ en $><$ label $>52</$ label $>$ Eugene Richter, Pictures of the Socialistic Future (London: Swan Sonnenschein \& co. 1907) available at http://www.econlib.org</en>

$<$ en $><$ label $>$ 53</label $>$ William Liebknecht, 'Our Recent Congress’, Justice, 15 August 1895. $</$ en $>$

$<$ en $><$ label $>54</$ label $>$ 'Celebrating the Commune', Daily News, 18 March 1887.</en>

$<$ en $><$ label $>55<$ /label $>$ Florence Boos, 'William Morris’s Socialist Diary', History Workshop

13 (1982), 38.</en>

$<$ en $><$ label $>56</$ label $>$ Ibid., 28 n. 56-58. $<$ en $>$

$<$ en $><$ label $>$ 57</label $>$ Ibid., 38 n. 106.</en $>$

$<$ en $><$ label $>$ 58</label $>$ Morris, Political Writings, pp. 180-183.</en $>$

$<$ en $><$ label $>59<$ label $>$ Ibid., p. 180. For Donnisthorp’s comments on Joynes see. Socialism

Analyzed. Being a Critical Examination of Mr. Joynes’s 'Socialist Catechism' (London:

Liberty and Property Defence League, 1888).</en>

$<$ en $><$ label $>60<$ label $>$ W. Morris, Collected Letters of William Morris, vol. III: 1889-1892, Norman Kelvin (ed.) (New Jersey: Princeton University Press, 1996), p. 59; Grant Allen, ‘Individualism and Socialism’, Contemporary Review LV (1889), 730-734.</en>

$<$ en $><$ label $>61<$ label $>$ Morris, Letters III, p. 88. $<$ en $>$

$<$ en $><$ label $>62<$ /label $>$ Justice, 5 September 1896.</en $>$

$<$ en $><$ label $>63<$ label $>$ Friedrich Engels, Letter to M. Hildebrand, in Marx, Engels, Lenin, p. 179. $</$ en $>$ 
$<$ en $><$ label $>64<$ label $>$ Morris, Letters III, p. 63. $<$ /en $>$

$<$ en $><$ label $>65<$ /label $>$ Ibid., p. 87. $</$ en $>$

$<$ en $><$ label $>66<$ /label $>$ Ibid., p. $63 .</$ en $>$

$<$ en $><$ label $>67<$ label $>$ Ibid., p. 64. $<$ /en $>$

$<$ en $><$ label $>68</$ label $>$ Morris, Letters II, p. 769. $<$ en $>$

$<$ en $><$ label $>69</$ label $>$ Morris, Letters III, p. 63. $<$ en $>$

$<$ en $><$ label $>70<$ label $>$ Ibid., p. $64 .<$ /en $>$

$<$ en $><$ label $>71<$ label $>$ Morris, 'Socialist Poet', p. 6. $<$ /en $>$

$<$ en $><$ label $>72<$ label $>$ Morris, Liberty, p. $14 .</$ en $>$

$<$ en $><$ label $>73<$ /label $>$ Morris, Letters II, p. 768. $<$ /en $>$

$<$ en $><$ label $>74<$ /label $>$ Ibid., p. 766. $<$ en $>$

$<$ en $><$ label $>75<$ label $>$ Morris, Liberty, p. 14. $</$ en $>$

$<$ en $><$ label $>76</$ label $>$ For a qualified anarchist defence of majoritarianism see A. Bertolo,

'Democracy and Beyond', Democracy and Nature: An International Journal of Inclusive

Democracy, 5(2) (1999) at http://www.democracynature.org/vol5/vol5.htm (access 28

November 2010).</en>

$<$ en $><$ label $>77<$ label $>$ William Morris, News From Nowhere, David Leopold (ed.), (Oxford:

Oxford University Press, 2003.), p. 77.</en>

$<$ en $><$ label $>78</$ label $>$ Ibid. $</$ en $>$

$<$ en $><$ label $>79<$ label $>$ Morris, Letters III, p. 64. $<$ en $>$

$</$ fn-group $>$ 